\title{
A Study on the Mediating Effect of Perceived Usefulness in the Acceptance of Airport Service Technology
}

\author{
${ }^{l}$ Hyeyoon PARK \\ 1. First Author Associate Professor, Hanseo University of Aviation Tourism, E-mail: hypark@hanseo.ac.kr \\ Received: January 13, 2020. Revised: March 4, 2020. Accepted: March 4, 2020.
}

\begin{abstract}
Purpose - In the aviation industry, we will investigate the impact of users' acceptance of technology on their usage behavior and find out the factors that affect their acceptance of technology. We will expand the prior study to find out the impact of the self-service technology of Incheon Airport.

Research design, data, and Methodology - The thesis was conducted on people using self-service technology at Incheon International Airport from July to August 2019. Part 307 of the valid questionnaires were used for this final analysis. The collected data were used to perform frequency, factor, reliability, and multiple regression analyses using the SPSS statistical package.

Result - Individual aspects of external variables, service aspects, and systems aspects have been shown to affect usability and perceived ease of use. Usability and convenience have been shown to serve as intermediaries for users' technological acceptance.

Conclusion - The perceived convenience and usefulness of Incheon International Airport has been shown to affect self-service users, while convenience and usefulness have been shown to serve as intermediaries for technology acceptance purposes. In other words, raising expectations for convenience, rapid processing, benefits and so on will have a positive impact on the intent to accept.
\end{abstract}

Keywords:IT Technology Acceptance, Perceived Ease of Use, Perceived Usefulness, Mediating Effect

JEL Classification Code: L15, L84, M31.

\section{Introduction}

The aviation industry is a dynamic transport industry, and air transport plays an important role in promoting globalization by facilitating the flow of people, goods and information (IATA, 2019). Due to defects in high-speed $5 \mathrm{G}$ and smart device technologies, each field of society is making rapid progress. In particular, technology-based self-service, which interacts with passengers in new ways, is rapidly being introduced in the aviation industry sector as the application of technology to services increases. 
In particular, the airport is the first gateway for passengers to begin their journey, and since the infrastructure of the airport has a significant meaningful impact on the perception of the passenger experience, self-service technologies for saving passenger time, reducing space strategy, and cost are widely implemented in the aviation industry. The airport's new information technology was divided into self-service technology and airport support technology, which said that ticket issuance, boarding and baggage processes could improve throughput as a major application area (Bogicevic et al., 2017; Kim \& Park, 2019), reducing costs and improving consumer services, as well as creating an image that leads the service's leading position (Byun, 2018; Chen \& Shang, 2018).

Incheon Airport's 2nd Passenger Terminal, which opened recently, is a state-of-the-art airport, and aims to drastically reduce the time required for passengers to and from the country and implement world-class smart airports by expanding self-service, such as self-check-in and automatic baggage claim.

As a result of creating and extending the "self-service zone" in the center, the waiting space of the 2nd Passenger Terminal at Incheon International Airport is three times larger than the 2nd Terminal, the utilization rate of the airport increased from $23 \%$ and $2.7 \%$ in 17 years, respectively, by self-checking and 115 by self-backing. Immigration time is also reduced by more than 30 percent(Kim \& Park, 2017; Rajasekhara \& Satagopam, 2018).

Therefore, we will examine the variables that affect the acceptance intention of self-service users for simplified procedures, enhanced security, and efficient work, and see how perceived usefulness and ease of use affect the acceptance intention of the technology in this study. In doing so, we would like to draw a suggestion that contributes to the airport's self IT service technology operation policy to encourage passengers to use the airport's self-service technology.

\section{Literature Review}

What factors users of information technology embrace is one of the most important meaningful research areas in recent years. Theoretical basis (Im et al., 2017; Gu \& Lee, 2019) for studying these skills is based on three models: Technology Acceptance Model (TAM), Theory of Planned Behavior (TPB) and Theory of Reasoned Action (TRA).

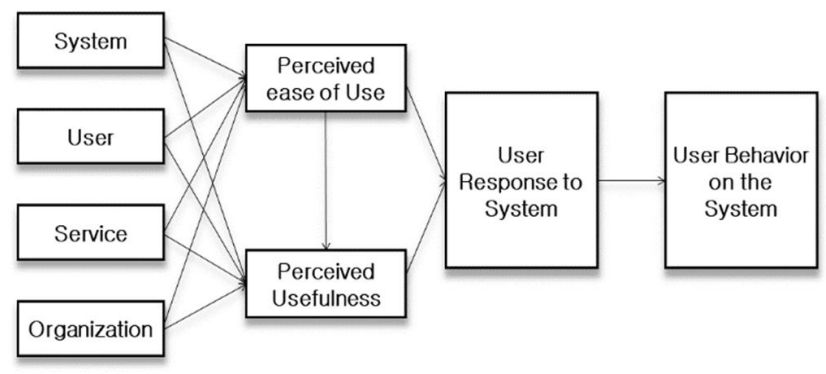

Figure 1: Basic Model of TAM

As such, TAM is a model that explains the factors that users embrace information technology. Currently, IT services are widely used and the scope of end users is expanding (Lee et al., 2016; Jin \& Lee, 2018). Also, it is possible to use digital products traded on the Internet only with basic knowledge to handle information technology such as the Internet and computers. Therefore, the use of TAM, which looks at computers and the Internet as information technology, and explains what factors influence the acceptance of information technology, was deemed appropriate, so TAM was introduced as a research model.

The individual aspect of the information technology sector was said to be the voluntary will of individuals to test new information technology, and the individual aspect would affect their intention to use new technology (Agarwal and Prasad, 1997). Agarwal and Karahana (2000) said that personal aspects are considered to be important determinants of cognitive immersion and have a meaningful impact on usefulness and ease of use, with five 
individual aspects. Therefore, this study defined the individual aspect as 'the degree of voluntary will of individuals to test new information technology'.

Rayport (1995) defined testability to the extent that innovation could be tried on a limited basis. In this study, it was defined as 'providing service use opportunities and degree of symbolism of functional testing'.

The characteristics of the system were similar in meaning to the performance and speed of the system used by Davis et al. (1989). That is, the system aspect is the extent that users can use the system reliably and efficiently. In this study, system aspects are defined as 'system stability and speed'.

Perceived ease-of-use took advantage of the key concepts presented in Davis et al. (1989)'s technology acceptance model. Perceived convenience is defined as 'the extent that users believe that using a particular system will reduce users' efforts.'

Perceived usefulness of IT service has been used in its entirety the core concepts presented in the technology acceptance model. Perceived usefulness of IT service is defined as 'the extent to that users believe it will improve job performance for users using a particular system.'

Davis et al. (1989) found that acceptance was 'intentional strength to use a specific information system'. Acceptance was a major factor in determining actual behavior, making actual behavior predictable from the intent to use. This study defined 'intentional or probability of using a service'.

\section{Sample and Methodology}

\subsection{Research model}

A research model based on prior research was proposed as shown in Figure2. We would like to explore how external variables affect perceived usefulness of IT service and perceived ease of use. And we also want to examine how ease-of-use and perceived usefulness affect technology acceptance intent through empirical analysis.

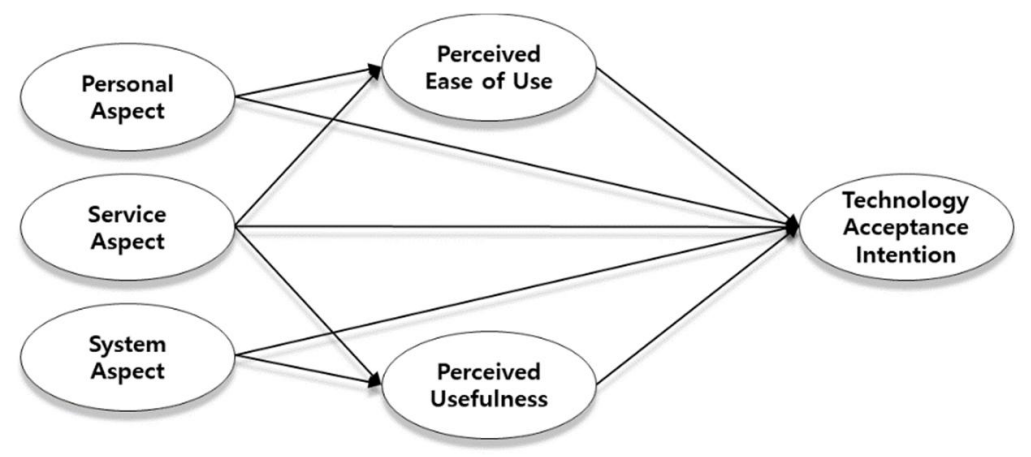

Figure 2: Research model

\subsection{Setting a hypothesis}

In situations where IT services are not mandatory, a higher degree of use of IT technology to enable users to use technology can make the system easier for users (Lee, 2011; Kim \& Park, 2017; Byun, 2018; Chen \& Shang, 2018; Kim \& Park, 2019). In other words, the use of an related information system by users is dependent on information systems. It has been shown that users of system aspect have a positive impact on the use and acceptance of technology by participating in the system development process. 
In this study, external variables are composed of individual variables, service variables, and system variables to verify how they affect perceived ease of use and usefulness. To this end, the following research theories were established:

H1: External Variables will have impact on the perceived ease of use.

H1-1: Personal aspect will have impact on the perceived ease of use.

H1-2: Service aspect will have impact on the perceived ease of use.

H1-3: System aspect will have impact on the perceived ease of use.

H2: External Variables will have significant impact on the perceived IT service usefulness.

H2-1: Personal aspect will have significant impact on the perceived IT service usefulness.

H2-2: Service aspect will have significant impact on the perceived IT service usefulness.

H2-3: System aspect will have significant impact on the perceived IT service usefulness.

Many prior studies have demonstrated a causal relationship that perceived ease-of-use influences the intent to use (Davis et al, 1989; Adam et al., 1992; Bharadwaj, 2000, Lee, 2011)

Perceived values are recognized as one of the major contributors variables to behavior (Park et al., 2012). Many studies have been conducted on the effects of perceived value of users on post-intelligence and behavior patterns. Zeithaml (1998) regarded perceived value as similar to perceived product value concepts, and said perceived value is the utility that is derived from the use of an information system.

Acceptance means the willingness, frequency of use, and time of use by technical users (Davis \& Bagozi, 1989; Venkatesh \& Bala, 2008; Kim \& Park, 2017). This will verify the impact of perceived usefulness on technology acceptance intent.

H3: Perceived ease of use on IT service will have a significantly positive influence on the technology acceptance intention.

H4: Perceived usefulness on IT service will have a significantly positive influence on the technology acceptance intention.

H5: Perceived easements and perceived acceptability will be mediated in the relationship between external variables and technology acceptance.

\section{Empirical Results}

\subsection{Demographic Characteristics}

Questionnaires were collected using random sampling method to verify the proposed hypothesis. The investigation period lasted for two months until July-August 2019. A total of 310, of which 307 were used for the analysis, excluding those with missing values. The demographic characteristics of the 307 samples are shown in [Table 1].

Table 1: Profile of Respondents

\begin{tabular}{|c|c|c|c|c|c|c|c|}
\hline \multicolumn{2}{|c|}{ Classification } & $\mathbf{n}$ & $\%$ & \multicolumn{2}{|c|}{ Classification } & n & $\%$ \\
\hline \multirow{2}{*}{ Gender } & Male & 179 & 58.3 & \multirow{5}{*}{$\begin{array}{c}\text { Number of } \\
\text { Use } \\
\text { (yearbasis) }\end{array}$} & $1-2$ & 133 & 43.3 \\
\hline & Female & 128 & 41.7 & & 34 & 107 & 34.9 \\
\hline \multirow{4}{*}{ Age } & \multirow{2}{*}{$20^{\prime}$} & \multirow{2}{*}{112} & \multirow{2}{*}{36.5} & & $5-6$ & 31 & 10.1 \\
\hline & & & & & \multirow{2}{*}{ Over 7} & \multirow{2}{*}{36} & \multirow{2}{*}{11.7} \\
\hline & $30^{\prime}$ & 104 & 33.9 & & & & \\
\hline & $40^{\prime}$ & 72 & 23.5 & Purpose of & Tour & 56.7 & 56.7 \\
\hline
\end{tabular}




\begin{tabular}{|c|c|c|c|c|c|c|c|}
\hline & & & & \multirow[t]{4}{*}{ Use } & \multirow{2}{*}{ Business Trip } & \multirow{2}{*}{29.6} & \multirow{2}{*}{29.6} \\
\hline & \multirow{2}{*}{ Over 50} & \multirow{2}{*}{19} & 6.2. & & & & \\
\hline \multirow{8}{*}{ Job } & & & & & \multirow[t]{2}{*}{ Visiting Relative } & \multirow[t]{2}{*}{13.7} & \multirow[t]{2}{*}{13.7} \\
\hline & Officer & 264 & 86.0 & & & & \\
\hline & & & & \multirow{6}{*}{$\begin{array}{l}\text { Origin } \\
\text { Of } \\
\text { Inform }\end{array}$} & Intemet & 187 & 60.9 \\
\hline & Student & 22 & 7.2 & & \multirow[t]{2}{*}{ Travel Agency } & \multirow[t]{2}{*}{68} & \multirow[t]{2}{*}{22.2} \\
\hline & \multirow{3}{*}{ Public Officer } & \multirow{3}{*}{6} & \multirow{3}{*}{2.0} & & & & \\
\hline & & & & & Recommendation & 29 & 9.4 \\
\hline & & & & & \multirow[t]{2}{*}{ Others } & \multirow[t]{2}{*}{23} & \multirow[t]{2}{*}{7.5} \\
\hline & Housewife & 4 & 1.3 & & & & \\
\hline
\end{tabular}

\subsection{Factor analysis and reliability analysis}

The validity of the constructive validity of the measurement tool was evaluated through the rational validity discrimination validity law validity. Internal consistency was assessed based on Cronbach 's $\alpha$ coefficient to evaluate the reliability of the measurement tool. For this construct validity and reliability, this study carried out confirmatory factor analysis using AMOS 18.0 and reliability analysis using SPSS 18.0. The confirmatory factor analysis results are presented in [Table 2]. The fit of the measurement model was inadequate as $\chi^{2}=508.836(\mathrm{df}=$ $215, \mathrm{p}=.000$ ), but it was not sensitive to the sample size and the number of observation variables. We also assessed the suitability considering the incremental fit index and the simplicity fit index. The goodness-of-fit of the model showed that the AGFI value was lower than the standard value, but overall, it was judged to be acceptable because it was above the standard value $\left(\chi^{2} / \mathrm{df}=2.367, \mathrm{RMR}=.063, \mathrm{GFI}=.915, \mathrm{AGFI}=.862, \mathrm{NFI}=.936, \mathrm{TLI}=.950, \mathrm{CFI}\right.$ $=.973, \mathrm{RMSEA}=.085)$. In addition, the values of standardized factor loadings of all the measurement items showed more than 0.5 , and the average variance extraction value (AVE) and concept reliability (CCR), which are the intensive validity evaluation methods suggested by Fornell and Larcker (1981), were all AVE>0.5 and CCR $>0.7$. In this study, it was judged that the criteria of this study were sufficient for concentration validity, and the Cronbach's $\alpha$ coefficient of all components was 0.6 or more, which ensured the reliability of the selected criteria.

Table 2: Confirmation Factor Anaylysis

\begin{tabular}{|c|c|c|c|c|c|c|c|}
\hline \multicolumn{2}{|c|}{ Measurement Item } & $\begin{array}{l}\text { Std.Factor } \\
\text { Loading }\end{array}$ & Std.Emor & C.R. & AVE & CCR & Cronbach's $\alpha$ \\
\hline \multirow{5}{*}{$\begin{array}{c}\text { Personal } \\
\text { Aspect }\end{array}$} & Personal Aspect 1 & .656 & & & \multirow{5}{*}{.501} & \multirow{5}{*}{.834} & \multirow{5}{*}{.828} \\
\hline & Personal Aspect2 & .652 & .135 & $9.643^{\star \star \star}$ & & & \\
\hline & Personal Aspect3 & .756 & .118 & $10.829^{* \star *}$ & & & \\
\hline & Personal Aspect4 & .753 & .122 & $10.806^{\star \star \star}$ & & & \\
\hline & Personal Aspect5 & .716 & .136 & $10.395^{\star \star \star}$ & & & \\
\hline \multirow{5}{*}{$\begin{array}{l}\text { Senvice } \\
\text { Aspect }\end{array}$} & Serviœ Asped 1 & .865 & - & - & \multirow{5}{*}{.609} & \multirow{5}{*}{.885} & \multirow{5}{*}{.882} \\
\hline & Servic Asped2 & .894 & .052 & $20.258^{* \star \star}$ & & & \\
\hline & Serviœ Aspect3 & .751 & .050 & $15.493^{* \star *}$ & & & \\
\hline & Serviœ Aspect 4 & .682 & .046 & $13.466^{\star \star \star}$ & & & \\
\hline & Servi Aspec5 & .686 & .060 & $13.603^{* \star *}$ & & & \\
\hline \multirow{2}{*}{$\begin{array}{l}\text { System } \\
\text { Aspect }\end{array}$} & System Aspect 1 & .814 & - & - & \multirow{2}{*}{.620} & \multirow{2}{*}{.867} & \multirow{2}{*}{.701} \\
\hline & System Aspect2 & .784 & .389 & $5.187^{\star \star \star *}$ & & & \\
\hline
\end{tabular}




\begin{tabular}{|c|c|c|c|c|c|c|c|}
\hline & System Aspect3 & .798 & .388 & $5200^{\star \star \star}$ & & & \\
\hline & System Aspect 4 & .753 & .381 & $5.154^{\star \star \star}$ & & & \\
\hline \multirow{3}{*}{$\begin{array}{c}\text { Perceived } \\
\text { Ease }\end{array}$} & Perceived Ease 1 & .815 & - & - & \multirow{3}{*}{.629} & \multirow{3}{*}{.836} & \multirow{3}{*}{.832} \\
\hline & Perceived Ease 2 & .778 & .072 & $14.811^{\star \star \star}$ & & & \\
\hline & Perceived Ease 3 & .786 & .066 & $14.997^{\star \star \star}$ & & & \\
\hline \multirow{3}{*}{$\begin{array}{l}\text { Perceived } \\
\text { Usability }\end{array}$} & Perceived Ease 1 & .855 & - & - & \multirow{3}{*}{.791} & \multirow{3}{*}{.919} & \multirow{3}{*}{.917} \\
\hline & Perceived Ease 2 & .906 & .054 & $21.494^{\star \star \star}$ & & & \\
\hline & Perceived Ease 3 & .906 & .054 & $21.513^{\star \star *}$ & & & \\
\hline \multirow{3}{*}{$\begin{array}{l}\text { Technology } \\
\text { Acœptanœe } \\
\text { Intention }\end{array}$} & $\begin{array}{l}\text { Acceptanœe } \\
\text { Intention } 1\end{array}$ & .818 & - & - & \multirow{3}{*}{.661} & \multirow{3}{*}{.867} & \multirow{3}{*}{.854} \\
\hline & $\begin{array}{l}\text { Acceptanœe } \\
\text { Intention2 }\end{array}$ & .856 & .065 & $17.043^{\star \star \star}$ & & & \\
\hline & $\begin{array}{l}\text { Acœptanœ } \\
\text { Intention3 }\end{array}$ & .763 & .067 & $14.674^{\star * \star}$ & & & \\
\hline \multicolumn{8}{|c|}{$\begin{array}{c}x^{2}=508.836(\mathrm{df}=215, \mathrm{p}=.000), x^{2} / \mathrm{df}=2.367, \mathrm{RMR}=.063, \mathrm{GFI}=.915, \mathrm{AGFI}=.862, \mathrm{NFI}=.936, \mathrm{TLI}=.950, \\
C F I=.973, \mathrm{RMSEA}=.085\end{array}$} \\
\hline
\end{tabular}

Finally, the relationship between all the latent variables is less than 0.7 . There is no need to doubt the multicollinearity. Therefore, it was judged that the discrimination validity between each construct was established. In addition, as shown in [Table 3], the validity of the law was also established by showing a positive relationship with the direction of the hypothesis established in this study. Therefore, the construct validity of the measurement tool of this study was judged to be sufficient.

Table 3: Descriptive Statistics and Correlation Anaylysis

\begin{tabular}{c|c|c|c|c|c|c|c|c}
\hline & Mean & S.D & $\begin{array}{c}\text { Personal } \\
\text { Aspect }\end{array}$ & $\begin{array}{c}\text { Service } \\
\text { Aspect }\end{array}$ & $\begin{array}{c}\text { System } \\
\text { Aspect }\end{array}$ & $\begin{array}{c}\text { Perceived } \\
\text { Ease }\end{array}$ & $\begin{array}{c}\text { Perceived } \\
\text { Usability }\end{array}$ & $\begin{array}{c}\text { Technology } \\
\text { Acceptance } \\
\text { Intention }\end{array}$ \\
\hline \hline $\begin{array}{c}\text { Personal } \\
\text { Aspect }\end{array}$ & 3.484 & .630 & $.501^{\mathrm{a}}$ & $.264^{\mathrm{b}}$ & $.324^{\mathrm{b}}$ & $.378^{\mathrm{b}}$ & $.311^{\mathrm{b}}$ & $.312^{\mathrm{b}}$ \\
\hline $\begin{array}{c}\text { Service } \\
\text { Aspect }\end{array}$ & 3.032 & .776 & .514 & $.609^{\mathrm{a}}$ & $266^{\mathrm{b}}$ & $.371^{\mathrm{b}}$ & $.227^{\mathrm{b}}$ & $.291^{\mathrm{b}}$ \\
\hline $\begin{array}{c}\text { System } \\
\text { Aspect }\end{array}$ & 3.477 & .618 & .569 & .516 & $.620^{\mathrm{a}}$ & $.482^{\mathrm{b}}$ & $.487^{\mathrm{b}}$ & $.448^{\mathrm{b}}$ \\
\hline $\begin{array}{c}\text { Perceived } \\
\text { Ease }\end{array}$ & 3.569 & .665 & .615 & .609 & .694 & $.629^{\mathrm{a}}$ & $.381^{\mathrm{b}}$ & $.466^{\mathrm{b}}$ \\
\hline $\begin{array}{c}\text { Perceived } \\
\text { Usability }\end{array}$ & 3.459 & .767 & .558 & .476 & .698 & .617 & $.791^{\mathrm{a}}$ & $.448^{\mathrm{b}}$ \\
\hline $\begin{array}{c}\text { Technology } \\
\text { Acceptance } \\
\text { Intention }\end{array}$ & 3.476 & .759 & .559 & .539 & .669 & .683 & .669 & $.661^{\mathrm{a}}$ \\
\hline
\end{tabular}

a. AVE Value, b. Square of Bivariate Correlation Coefficient( $\left(^{2}\right)$

\subsection{Hypothesis Verification}


The results of analyzing the structural equation model for the hypothesis verification in this study are shown in $<$ Table $4>$ and $<$ Figure $1>$. The fitness of this study was $\left(\chi^{2}=540.237(\mathrm{df}=216, \mathrm{p}=.000)\right)$ which showed inadequateness as in the confirmatory factor analysis, but it was not possible to determine the goodness of fit just because its significance is sensitive on the sample size and the number of observation variables. We assessed the suitability considering the Incremental Fit Index and the Incremental Fit Index and the Simplicity Fit Index. The AGFI was found to fall short of the standard, but overall it was above the threshold. $\left(\left(\chi^{2}=540.237(\mathrm{df}=216, \mathrm{p}\right.\right.$ $\left.=.000), \chi^{2} / \mathrm{df}=2.501, \mathrm{RMR}=.062, \mathrm{GFI}=.909, \mathrm{AGFI}=.855, \mathrm{NFI}=.929, \mathrm{TLI}=.944, \mathrm{CFI}=.966, \mathrm{RMSEA}=.087\right)$.

Table 4: Structural Equation Model Analysis

\begin{tabular}{|c|c|c|c|c|c|}
\hline & Path & Std.Factor & Std.Error & t-value & p-value \\
\hline \multirow{3}{*}{$\mathrm{H} 1$} & Personal Aspect $\rightarrow$ Perøived Ease & .246 & .062 & 4.493 & *** \\
\hline & Senvice Aspect $\rightarrow$ Perceived Ease & .291 & .031 & 5.688 & *** \\
\hline & Sytem Aspect $\rightarrow$ Perceived Ease & .753 & .437 & 3.805 & $\star * \star$ \\
\hline \multirow{3}{*}{$\mathrm{H} 2$} & Personal Aspect $\rightarrow$ Perœeived Usability & .253 & .070 & 4.641 & 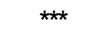 \\
\hline & Serviœ Aspect $\rightarrow$ Perœived Usability & .144 & .034 & 2.932 & .003 \\
\hline & Sytem Aspect $\rightarrow$ Perœived Usability & .672 & .448 & 3.784 & *** \\
\hline $\mathrm{H} 3$ & $\begin{array}{c}\text { Perceived Ease } \rightarrow \text { Acceptance } \\
\text { Intention }\end{array}$ & .111 & .04 & 2.885 & .004 \\
\hline $\mathrm{H} 4$ & $\begin{array}{c}\text { Perœived Usability } \rightarrow \text { Acceptanœ } \\
\text { Intention }\end{array}$ & .661 & .085 & 7.903 & *** \\
\hline \multirow{3}{*}{ H5 } & $\begin{array}{l}\text { Personal System } \rightarrow \text { Acceptanœ } \\
\text { Intention }\end{array}$ & .039 & .081 & 639 & .523 \\
\hline & Serviœ Aspect $\rightarrow$ Acceptanœ Intention & .129 & .042 & 2.162 & .031 \\
\hline & Sytem Aspect $\rightarrow$ Acceptance Intention & .125 & .344 & .928 & .353 \\
\hline \multicolumn{6}{|c|}{$\left(x^{2}=540.237(\mathrm{df}=216, \mathrm{p}=.000),\left(\chi^{2} / \mathrm{df}=2.501, \mathrm{RMR}=.062, \mathrm{GFl}=.909, \mathrm{AGF}=.855, \mathrm{NFl}=.929, \mathrm{TL}=.944, \mathrm{CF}=.966, \mathrm{RMSEA}=.087\right.\right.$} \\
\hline
\end{tabular}

As a result on verifying the effect of the external variable $\mathrm{H} 1$ on perceived ease, the standardized path coefficient of the influence of the personal aspect H1-1 on perceived ease was .246 , with $t=4.493$ ( $p<.001$ ). Statistically significant effect. Thus, 'H1-1: Personal aspects will have a significant impact on perceived ease'. The standardized path coefficient of the impact of service aspect of H1-2 on perceived ease of use was .291 , and $t=5.688(p<.001)$ showed statistically significant effect. H1-2: The aspect of service will have a significant impact on perceived ease. The standardized path coefficient of the influence of personal aspects of H1-3 on perceived ease was .753, and $\mathrm{t}=3.805$ ( $\mathrm{p}<.001)$, which was statistically significant. H1-3: The system aspect will have a significant impact on perceived ease.

As a result on verifying the influence of the external variable of $\mathrm{H} 2$ on perceived usefulness, the standardized path coefficient of the influence of the personal aspect of H2-1 on perceived usability was .253, $t=4.641$ ( $p<.001)$. Statistically significant effect. Thus, H2-1: Personal aspects will have a significant impact on perceived usability. The standardized path coefficient of the impact of the service aspect of H2-2 on the perceived usability was .144 and $\mathrm{t}=2.932(\mathrm{p}<.01)$ showed a statistically significant effect. Thus, H2-2: Service aspects will have a significant impact on perceived usability. The standardized path coefficient of the influence of the personal aspect of H1-3 on the perceived usability was .672 and $t=3.784(p<.001)$ was statistically significant. H2-3: The system aspect will have a significant impact on perceived usability.

As a result on verifying the effect of $\mathrm{H} 3$ perceived ease on technology acceptance intention, the standardized path coefficient of the influence of perceived ease on technology acceptance intention was .111 , with $\mathrm{t}=2.885(\mathrm{p}<.01)$. Statistically significant effect. Thus, H3: Perceived ease will have a significant impact on technology acceptance 
intention. Verifying the influence of the perceived usability of $\mathrm{H} 4$ on the technology acceptance intention, the standardized path coefficient of the impact of the perceived usefulness on the technology acceptance intention was .661, with $\mathrm{t}=7.903(\mathrm{p}<.001)$. Statistically significant effect. Thus, H4: Perceived usability will have a significant impact on technology acceptance intention.

On a result of verifying the effect of the external variable of H5 on the technology acceptance intention, the standardized path coefficient of the effect of the personal aspect of H5-1 on the technology acceptance intention was .039, and $t=.639$ ( $\mathrm{p}>$. 05) did not have a statistically significant effect. Thus, it was rejected that 'H5-1: Personal aspects will have a significant effect on technology acceptance intention.' The standardized path coefficient of the H5-2 service aspect on technology acceptance intention was .129 and $\mathrm{t}=2.162(\mathrm{p}<.05)$, which was statistically significant. H5-2: The service aspect will have a significant impact on technology acceptance intention. The standardized path coefficient of H5-3's individual aspect on skill acceptance intention was .125 and $\mathrm{t}=.928(\mathrm{p}>.05)$, indicating no statistically significant effect. Therefore, it was rejected that 'H5-3: System aspect will have a significant effect on technology acceptance intention.'

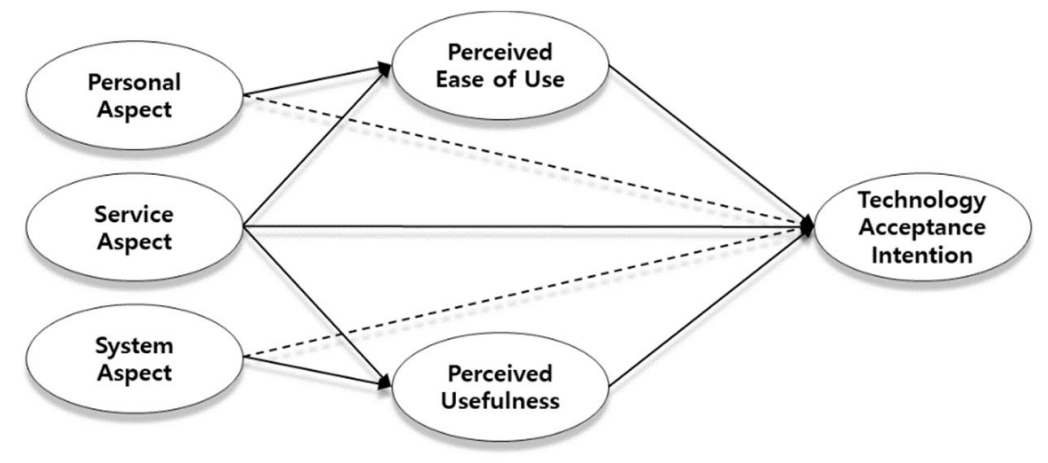

Figure 3: Structural Equation Model Analysis Results

On the other hand, bootstrap was used to verify the mediating effects of perceived ease and perceived usefulness in the relationship between external variables and technology acceptance intention. The analysis results are shown in $<$ Table 5>. As a result of verifying the mediation effect of perceived ease in the relationship between external variables and technical acceptance intention, H6-1, the mediating role of perceived ease in the relationship between personal aspect and technology acceptance intention. The standardized path coefficient was .125 ( $\mathrm{p}=.007)$, and the personal aspect did not have a direct effect on technology acceptance intention $(\beta=.115, p=.157)$. It was found to play a full role in the relationship of acceptance intention. H6-1: Perceived ease will play a mediating role in the relationship between personal and technical acceptance intentions. As a result of verifying the mediation role of perceived ease in the relationship between service aspect of H6-2 and technology acceptance intention, the standardized path coefficient of mediation effect was $.129(\mathrm{p}=.005)$, and the service aspect of technology acceptance The perceived ease of use was completely mediated in the relationship between service aspect and technology acceptance intention. Therefore, 'H6-2: Perceived ease of use will act as a mediator in terms of the relationship between service aspects and technology acceptance intentions.' As a result of verifying the mediation role of perceived ease in the relationship between H6-3 system aspect and technology acceptance intention, the standardized path coefficient of mediation effect was .247 $(\mathrm{p}=.012)$. The perceived ease of use was shown to have a direct effect on the plot $(\beta=.302, \mathrm{p}=.028)$. Therefore, 'H6-3: Perceived ease will play a mediating role in the relationship between system aspect and technology acceptance intention.'

Verification of the medial effect of perceived usability in relation to the influence of external variables and technical acceptability of $\mathrm{H} 7$ and verification of the mediating role of perceived usability in relation to the personal aspect of H7-1 and the effect of technical acceptability indicated that the standard path coefficient of the standardized path coefficient was $.187(\mathrm{p}=.007)$, and the individual aspect did not directly affect the acceptability of the technology $(\beta=.053, p=.373)$. Perceived usability has been shown to play a full mediating role in the relationship 
between personal aspects and the intent to accept technology. Therefore, 'H7-1: Perceived usability will play a mediating role in the relationship between individual aspects and the influence of technical acceptability' was adopted. Validation of the perceived role of usability in relation to the impact of service aspects and technical acceptance intetion of H7-2 shows that the standard path coefficient for the mediating effect is $.111(\mathrm{p}=.037)$, and that the service aspect has a direct influence on the acceptance of the technology $(\beta=.149, p=.013)$

Therefore, 'H7-2: Perceived usefulness will play a mediating role in the relationship between the service aspect and the technology acceptance intention'. The standardized path coefficient for the perceived usefulness of the system aspect and the influence of the technical acceptability of H7-3 is shown in $.407(\mathrm{p}=.028)$ and the system aspects are shown to have a direct effect on the technical acceptability $(\beta=.170, \mathrm{p}=.011)$. Perceived usability has been shown to play a partial mediating role in the relationship between system aspects and technology acceptance intention. Therefore, 'H7-3: Perceived usability will play a mediating role in the relationship between the system aspect and the technical acceptability'.

Table 5: Validate the Mediation Effect with Bootstrap

\begin{tabular}{|c|c|c|c|c|c|c|c|c|}
\hline & & \multirow{2}{*}{ Path } & \multicolumn{2}{|c|}{ TotalEffect } & \multicolumn{2}{|c|}{ IndirectEffect } & \multicolumn{2}{|c|}{ DirectEffect } \\
\hline & & & Std.Coefficient & p-value & Std.Coefficient & p-value & Std.Coefficient & p-value \\
\hline \multirow{3}{*}{$\mathrm{H} 6$} & \multirow{3}{*}{$\begin{array}{l}\text { Perceived } \\
\text { Ease } \\
\text { (Mediating) }\end{array}$} & $\begin{array}{c}\text { Personal Aspect } \rightarrow \text { Acceptanœ } \\
\text { Intention }\end{array}$ & $.240^{\star *}$ & .007 & $.125^{\star *}$ & .007 & .115 & .157 \\
\hline & & $\begin{array}{l}\text { Service Aspect } \rightarrow \text { Acœeptance } \\
\text { Intention }\end{array}$ & $.270^{* *}$ & .009 & $.129^{* \star}$ & .005 & .141 & .070 \\
\hline & & $\begin{array}{c}\text { System Aspect } \rightarrow \text { Acceptanœ } \\
\text { Intention }\end{array}$ & $.549^{\star *}$ & .006 & $.247^{*}$ & .012 & $.302^{*}$ & .028 \\
\hline \multirow{3}{*}{$\mathrm{H} 7$} & \multirow{3}{*}{$\begin{array}{l}\text { Perceived } \\
\text { Usability } \\
\text { (Mediating) }\end{array}$} & $\begin{array}{l}\text { Personal Aspect } \rightarrow \text { Acceptance } \\
\text { Intention }\end{array}$ & $.240^{\star \star}$ & .009 & $.187^{\star \star}$ & .007 & .053 & .373 \\
\hline & & $\begin{array}{l}\text { Service Aspect } \rightarrow \text { Acceptanœ } \\
\text { Intention }\end{array}$ & $.260^{*}$ & .011 & $.111^{*}$ & .037 & $.149^{*}$ & .013 \\
\hline & & $\begin{array}{l}\text { System Aspect } \rightarrow \text { Acœeptance } \\
\text { Intention }\end{array}$ & $.577^{* *}$ & .004 & $.407^{*}$ & .028 & $.170^{*}$ & .011 \\
\hline
\end{tabular}

$\equiv: * * *<.001 . * *: p<.01,{ }^{* *}: p<.05$

\section{Discussions}

This study began with the assumption that individuals will have a different intention of accepting technology depending on their beliefs or attitudes and will affect their use of IT services at Incheon International Airport. The analysis was conducted to identify factors that increased the acceptance of IT service technologies by airport users. In addition, a hypothesis was established that the usefulness and convenience of recognizing technology would be mediated in the intent of accepting technology and a demonstration was conducted. The results of the empirical analysis are as follows.

The individual and system aspects have a significant impact on perceived easements and perceived importance. In other words, perceived ease and perceived importance in the airport's IT services increase the acceptance of technology. The TAM study, which is the basis of the research model of this study among existing prior studies, shows that external environment variables are influencing technology acceptance, which is fundamentally different from the previous study.

In this study, external environment variables are set as primary independent variables, making them easy and useful as parameters. In other words, it is meaningful in that the new factors have been verified by presenting a new research model suitable for the airport service study. There are some specific implications for this study. First, it 
provided criteria for classifying and comparing IT services that had been used as a means of comparing physical products by their attributes. Second, it provided a shift from an academic approach to airport IT services to an acceptance of information technology. Third, greater awareness of the usefulness and ease of airport IT service technologies has a positive impact on the willingness to accept technology. In other words, usefulness and ease of use are intermediaries in the purpose of technical acceptance. In other words, the acceptance of technology increases when there is a perception of the usefulness and ease of use of airport IT services. It is considered that the results of these empirical analyses can be broadly applied not only to the airport service sector but also to various convergence industries.

However, this study has several limitations: First, variables derived from prior studies are factors derived from past studies of the acceptance factors of the information system. Future research should elicit and validate influential factors in deriving the recognition, utilization and effectiveness of airport IT technologies and services. The subject of the investigation for empirical analysis is also temporary and limited. Further studies may suggest more effective implications if studies are conducted on a variety of topics.

\section{References}

Adams, D. A., Nelson, R. P., \& Todd, R. A. (1992). Perceived Usefulness, Ease of Use and Usage of Information Technology; A Replication, Mis Quarterly, 16(2), 227-247.

Agarwal, R., \& Karahanna, E. (2000). Time File When You're Having Fun: Cognitive Absorption and Beliefs About Information Technology Usage, MIS Quarterly, 24(4), 665-694.

Agarwal, R., \& Prasad, J. (1997). The Role of Innovation Characteristics and Perceived Voluntaries in the Acceptance of Information Technologies, Decision Sciences, 28(3), 557-582.

Bharadwaj, A. S. (2000). A Resource-Based Perspective on Information Technology Capability and Firm Performance: An Empirical Investigation, MIS Quarterly, 24(1), 169-196.

Bogicevic, V., Bujisic, M., Bilgihan, A., Yang, W., \& Cobanoglu, C. (2017). The impact of Traveler-Focused airport technology on traveler satisfaction. Technological Distribution (2nd ed.). Forecasting \& Social Change.

Byun, S. K. (2018). Evaluating Information Technology Systems Using Consumer Surveys: The Role of Personal Product Knowledge, Journal of Asian Finance, Economics and Business, 5(4), 117-125.

Chen, Y., \& Shang Y. F. (2018). Factors Influencing User's Word-of-Mouth Intention Regarding Mobile Apps: An Empirical Study, International Journal of Industrial Distribution \& Business, 9(1), 51-65.

Davis, F. D., \& Bagozzi, R. (1989). User Acceptance of Computer of Two Theoretical Models, Management Science, 35(8), 982-1003.

Davis, F.D., Bagozzi, R.P., \& Warshaw, P. P. (1989). User Acceptance of Computer Technology: A Comparison of Two Theoretical Models, Management Science, 35(8), 9-21.

Gu, W., Bao, P., \& Lee J. H. (2019). A Study on the Continuance Intention of O2O Fresh Agricultural Products ECommerce, International Journal of Industrial Distribution \& Business, 10(10), 35-44.

IATA (2015). International Air Transport Association(IATA) Economic Performance of the Airline Industry-Midyear 2015 Forecast Presentation. www.iata.org

Im, K. J., \& Kim, H, R., \& Yang, H. C. (2017). The Effectiveness on the Perception of Service Quality in MRO Transactions, The East Asian Journal of Business Management, 7(4), 11-15.

Jin, P. R., \& Lee, J. H. (2018). A Study on the Use Intention of Xiaomi in Korean Market, International Journal of Industrial Distribution \& Business, 9(11), 17-24.

Kim, C. S., \& Park, S. B. (2017). A Unified Model Combining Technology Readiness Acceptance Model and Technology Paradox Theory. Journal of Distribution Science, 8(7), 39-49.

Kim, J. H ., \& Park, J. W. (2019). The Effect of Airport Self-Service Characteristics on Passengers' Technology Acceptance and Behavioral Intention. Journal of Distribution Science, 17(5), 29-37.

Lee, J. H. (2011). The Influence of Perceived Usefulness and Perceived Ease of Use of Experience Store on Satisfaction and Loyalty. Journal of Distribution Science, 9(3), 5-14.

Lee, J. W., \& Becker, K., \& Potluri, R. M. (2016). Antecedents of Corporate Adoption of Social Media and the Role of the Technology Acceptance Model in the Path, Journal of Asian Finance, Economics and Business, 3(2), $67-76$. 
Rajasekhara, M. P., \& Satagopam, P. T. (2018). Challenges of Transport Sector in India: A Dyadic Perspective, Journal of Asian Finance, Economics and Business, 5(3), 95-102.

Rayport, J. F., \& Miller, V. E. (1995). How Information Gives You Competitive Advantage, Harvard Business Review, 78(Jul.-Aug.), 149-160.

Venkatesh, V., \& Bala, H. (2008). Technology Acceptance Model 3 and Research Agenda on Interventions, Decision Sciences, 39(2), 279-315.

Zeithaml, V. A. (1998). Consumer Perceptions of Price, Quality and Value: A Means-End Model and Synthesis of Evidence, Journal of Marketing, 52(3), 2-22. 